\title{
The Exploration on the Development Mode of Airport Industry
}

\author{
Yongming Zhu and Hao Zhang \\ School of Management and Engineering, Zheng Zhou University, Hen Nan, China
}

\begin{abstract}
Airport industry is a new platform of the global allocation of resources. It is indeed necessary that we need start with the basic theory. Also, we need classify the airport industry and discuss the type of airport industry and the development model. According to the international development experience, this article summarizes the development modes and the present situations of the airport industry. On this base, this paper summarized the successful experience, and induct some inspiration.
\end{abstract}

\section{Introduction}

The airport industry, also known as the "airport economy", relying on the aviation hubs, the airport attraction and radiation force with a specific industrial structure and spatial form so as to promote the capital, labor, technology, knowledge, management and other factors of production to the airport and its surrounding gathered, and has enormous influence as a new form of regional economic that consists of air transport industry, air transport services and aviation industry.

These industries briefly cover: air transport, air transport-related logistics, processing, high-tech industries, commercial and other services. The airport industry is a new economic model with regional economic system, which is based on the advantages of machine flow, logistics, information flow and capital flow. It is a new type of service model with modern service characteristics and the new economic characteristics of the new era of industry. The tremendous effects of air transport make production, technology, capital, trade, population aggregation in the airports adjacent to the airport and along the airport corridor which to form the multifunctional economic zone - airport economic zone.

From the domestic and foreign practices, the airport economic zone are mostly concentrated in the airport around 6$20 \mathrm{~km}$ range, or in the airport traffic corridor along the 15-minute drive to the airport as the core, to develop airport industry, airport and the formation of interrelated, Interdependence, mutual promotion of interaction.

According to domestic and international experience, the airport's investment efficiency ratio is $1: 8$, in fact it is a low-input and high-output industries.

A lot of local governments in China have come to realize the importance of relying on the airport, and have begun planning and develop the "airport economic zone", and thus effectively stimulate the development of regional economic. For example, Heilongjiang Mohe Airport, which is a county-level airport, the cost of operating less than 20 million each year, and has about 60 airport's manager. It will provide revenue to Mohe's border trade, tourism, logistics and other areas after the completion of the airport. In terms of the benefit ratios of $15 \%$, when the revenue from the airport is more than 3 billion, the profit generated from it will reach 45 million.

For example, the United States, as the world's largest aviation economy, the international airport association of north America released the "economic effects of commercial airports" (2010) analysis shows that: in terms of employment in 2010, the US civil airport and related fields to create 10.5 million or 7 percent of the US workforce (139 million), the airport is the second largest employer in the US after Wal-Mart, based on direct hiring. In terms of total annual salaries, the airport's total annual salary in 2010 was $\$ 365$ billion, equivalent to the size of Michigan's economy. In terms of GDP contribution, civil airports create a GDP value of \$ 1.2 trillion, which is higher than the total value of all goods and services produced in Mexico, Switzerland and South Korea, and the airport creates economic effects that account for more than 8 percent of US GDP.

\section{The development model of airport industry}

The emergence of airport industry is the the product of world's high-tech industries and the rapid development of global economic integration. The Shannon airport in Ireland began to try in 1959. As a trans-Atlantic transshipment station, Shannon airport set up the Shannon international airport free trade zone, relying on convenient transportation conditions and huge passenger flow and logistics. It attracted a lot of domestic and foreign capital and raw materials, and developed processing and export industries, which led to the rise of local economic and social.

Since the founding of Shannon international airport free trade area, the international industrial began a sustained practice and exploration on the industry layout of airport economy. the international community has gradually formed several airport industry development model after more than 10 years of practice. 


\section{The typical development model of foreign airport industry}

\subsection{Shannon International Airport Free Trade Zone, Ireland}

The Shannon international airport free trade zone of Ireland is characterized by the airport industrial zone. Shannon international airport free trade zone is established in Ireland in 1959, using its advantages about the location of the only route across the Atlantic, mainly for transit through the aircraft to provide, refueling, maintenance and other aviation support services, while the use of foreign capital and raw materials export processing industry. With the continuous development of science and technology, Shannon free trade zone gradually tend to upgrade to the aviation industry, and introduced lots of high-tech industry like communications information, electronic product manufacturing, software development, etc. In addition, the national aeronautical research center of Ireland was also established.

\subsection{The Memphis airport economic zone in United States}

Memphis airport economic zone is dominated by aviation logistics industry; it is the common development of various industries. Memphis aviation logistics industry benefited from the Federal Express, FedEx, driven by the aviation logistics industry chain enterprises in the various areas around the airport gathered to form a complete aviation logistics industry chain, the air logistics industry to become Memphis-led industry. At the same time, the aviation logistics industry led to the development of many industries around the airport, such as auto parts, medical equipment, biomedicine, electronic communications. FedEx maked Memphis air logistics industry prosperous, and aviation logistics industry further affected the development of other industries.

\subsection{The Frankfurt airport logistics park, Germany}

The main development characteristic of Frankfurt airport logistics park is business logistics. Frankfurt is located in the center of Germany, with Germany's largest air station and railway hub, Rhine - Meiyin airport is Europe's second largest airport, and also the important transit center in Europe. Relying on the global air transport network which is the center of the airport and all over the world, Frankfurt, give full play to the traditional advantages of trade center, to develop the financial industry and exhibition industry. In the vicinity of the airport, hundreds of logistics and transport companies stationed in Germany to manufacture large-scale machinery and equipment and key parts, cars and auto parts in the world can be promptly supply, which makes Frankfurt become Germany's major industrial and commercial, international exhibition, financial and transportation center, also known as the "Rhine River Manhattan."

\subsection{Korea Incheon airport international aviation city}

Korea Incheon airport is a multi-functional aviation city model. Incheon airport economic zone includes the airport area, international business district, free trade and tourism development zone, the Korean government is ready to develop the airport into a shipping, logistics, finance in 2011, and also introduced the Incheon airport airport development plan, high-tech in a body with a variety of industrial functions of the economic region. In the industry supporting, the South Korean government plans to introduce logistics, IT-based 64 green growth industries, products related to semiconductor and related components, network and communications equipment, computer software, medical and medical products by 2020. In the facilities, a large amount of land is reserved around Incheon airport for the construction of business and exhibition center, entertainment facilities, gaming hotels, shopping and leisure areas and other cultural experiences and recreational facilities.

\subsection{Netherlands Schiphol airport economic zone}

The characteristics of industry in Netherlands Schiphol airport economic zone is a variety of industries integrated development. Schiphol airport in Amsterdam, the Netherlands, continued to maintain the fourth passenger traffic in the European airports, the third place in cargo volume, is the base for air France, Lufthansa. From the initial simple airports to the development of a diversified and integrated aeronautical city, Schiphol Airport has created sustainable value for its stakeholders. Its excellent traffic conditions have attracted more than 200 international logistics operators to operate there. Many of the world's top 500 enterprises in Europe headquarters, close to the Schiphol Airport World Trade Center become the headquarters of many multinational trading company locations. At present, the Amsterdam airport economic zone covers industries such as flowers and vegetables, IT, aerospace, automotive, pharmaceutical, electronics, finance, entertainment and shopping, etc.

\subsection{Industrial base in Bangalore, India}

Bangalore, India industrial base is supported by high-tech industries. Bangalore has set up electronic city and international computer software technology park around the airport. It attracts many world-class elite technical talents 
and scientists, and actively develops the business of software design outsourcing. International famous companies such as Intel and Microsoft, IBM, Siemens, General Electric, HP, Compaq, Oerick, Acer have set up development centers and production bases in Bangalore, it has become the largest offshore software development outsourcing base of Silicon Valley now.

\subsection{Dubai, United Arab Emirates airport}

The main development industry of Dubai, the United Arab Emirates is the airport shopping tourism. Dubai Airport is the largest airport in the Middle East, Dubai air city in the industrial label is undoubtedly a unique tourist shopping, leisure and free trade zone. Duty-free shopping center can attract a large number of airport visitors, and is also the platform which can embody the values of business value directly. Dubai International airport duty free shop is the middle east and north Africa's largest duty-free goods retail store, the store's transit passenger spending of more than 30 US dollars per capita, ranking first in the world. Dubai's duty-free shopping area reached 9,000 square meters. In addition, it has gorgeous facilities, elegant environment, and world-renowned brands, and also keep pace with Europe and the United States in popular fashion Making it a truly world-class shopping airport.

\section{The development status of China's airport industry zone}

\subsection{Beijing airport economic core area}

The establishment of Beijing airport economic core area was approved by the Beijing Municipal Organization Committee in March 25, 2014. The core area is one of the six key high-end industrial functional areas in Beijing. The total planned area is about 178 square kilometers. It covers an area of about 56 square kilometers and consists of three functional areas, including the Beijing Tianzhu airport economic development zone, the former Beijing airport logistics base and the former Beijing Guomen Business District (including the Capital Airport of 27 square kilometers). This area collects the enterprises such as Air China, China Eastern Airlines, China Eastern Airlines, China Southern Airlines, Aviation Aviation, Aviation Materials, SF Express, and other strategic emerging industries such as the National Geographic Information Industry Park, and other industrial and financial enterprises such as Huaxia Fund and Kokai Innovation Capital, Yachang, airport advertising and other cultural and creative enterprises and the New China International Exhibition Center and other exhibition categories of enterprises, there are more than 2,000 enterprises in the core area, including Procter \& Gamble, PetroChina and more than 50 world top 500 projects. In 2014, the core area achieved territorial tax totaled 8.25 billion yuan, an increase of $26 \%$, accounting for $12 \%$ of Shunyi District, and local public revenue 2.4 billion, an increase of $17 \%$, accounting for $22 \%$ of Shunyi District.

\subsection{Tianjin airport economic zone}

It is one of the important functional areas of Tianjin Binhai New Area, and also a national aviation high-tech industry base relies on the scientific research resources of China Civil Aviation University and the convenient conditions of Tianjin Binhai International Airpor, with the airport logistics processing zone as a medium. According to the industrial development plan, it will build civil aircraft integrated assembly base, aviation industry gathering base, national aviation industry clusters innovation base, airport air traffic control and general aviation equipment R\&D and manufacturing base.

Tianjin airport industrial park sticks to the policy of "market traction, policy guidance, open cooperation, breakthroughs and supporting follow-up", and breakthroughs in institutional and institutional innovation, in line with local conditions and scientific planning, and actively develop aviation manufacturing, Aviation logistics, aviation education and training and aviation business service industry. It will become a new aviation industry base with the largest scale, perfect complement and internationalization in Asia, with obvious effect of industry agglomeration and rooting, brand effect and demonstration effect.

At present, the aviation industry of the airport industry has begun to take shape, attracting 17 aviation projects with a total investment of over 2 billion US dollars, including 10 foreign-funded projects and 7 domestic projects, including Airbus A320 series aircraft assembly line, AVIC helicopter industry The United States Goodrich aircraft nacelle, France Zuo Diyagao aviation equipment maintenance, Thales radar assembly, STTS aircraft painting services, Canada FTG aviation instrument panel, the German Lufthansa air cargo and HNA lease holding, the Xinhua logistics, etc. Worldclass aviation projects, involving aircraft assembly, research and development, spare parts manufacturing, aviation leasing, logistics and services and other fields.

\subsection{Shanghai Hongqiao airport economic park}

The planned Shanghai Hongqiao airport economic park covering an area of 5.14 square kilometers, adjacent to Hongqiao international airport. With the unique advantages of the Hongqiao international business district, the park is the largest Hongqiao integrated transportation hub in the world. it is also the largest transportation hub in the world. It 
has become the western core of the development of modern service industry in Shanghai Golden Corridor with the superiority of service and support of innovative environment, the advantages of clustering many well-known corporate headquarters, connecting the entire Yangtze River Delta region, the Yangtze River Basin region one of the most Vitality and radiation of the modern service industry cluster area.

The airport has initially formed three major industrial agglomeration of the situation, the formation of the information service industry-based modern service industry cluster situation: Ericsson, Staples, Synnex, Digital China, BenQ, Ctrip and other information industry leader More than 20 well-known headquarters enterprises at home and abroad to take root in the air, including the world's top 500 regions (the world's top 500 enterprises in the world), the United States, Headquarters of the 8; the formation of the aviation service industry, modern logistics industry agglomeration of the situation, FedEx, TNT, Jin Da International, Hong Lin International, Yangtze River Express, a large number of international freight logistics company has also brought together.

\subsection{Zhengzhou airport economic comprehensive experimental zone}

The State Council formally approved the "Zhengzhou airport economic development experimental zone development plan (2013-2025)" on March 7, 2013, Zhengzhou airport economic comprehensive experimental zone (hereinafter referred to as the Zhengzhou airport port) became the first national strategy and the first area of economic development of the airport. In 2014, the fixed asset investment in the region completed 40.1 billion yuan, an increase of 91.8\%; GDP completed 41.3 billion yuan, an increase of 18\%; above-scale industrial added value (the value-added industrial added value) Completed a total of 34.3 billion yuan, an increase of $21 \%$; large-scale industrial main business income of 209 billion yuan, an increase of $17.7 \%$; public budget revenue 2.12 billion yuan, an increase of $40.4 \%$; total import and export of 37.92 billion US dollars, $58.3 \%$ of the province.

The passenger throughput is 15.8 million in 2014, an increase of $20.3 \%$; cargo throughput of 370,000 tons, an increase of $44.9 \%$; two growth rates are ranked the first large airport. The total number of routes to 185 , navigation city 97. In particular, air cargo, new cargo routes 9 , a total of 32 , of which all international shipping routes 28 , continue to lead the inland, initially built up a global coverage of air cargo network.

At present, the Zhengzhou airport comprehensive economic experimental zone is developing aviation logistics, aviation preference high-end manufacturing industry and modern service industry, and strive to build a modern global aviation metropolis with Unicom global, ecological livable, intelligent innovation.

\section{The experience of foreign airport industry development}

\subsection{Integrated transport hub is the basic condition of the economic development of the airport}

It is not difficult to find that extending in all directions of the multi-modal transport system is the basic condition of the construction of the airport through the comparative analysis of the international mainstream airport development experience. For example, Memphis is located on the Mississippi River, with the world's leading air cargo airport, five first-class rail companies, the fourth largest US inland port and seven US national and intercontinental highways, cargo containers can be reached in 10 hours by truck The United States local 2/3 of the region, two-hour range can cover all the major cities in the United States, convenient surface and air transport is more conducive to saving transportation costs. Frankfurt is located in Germany's busiest intersection of two highways, with Europe's largest railway station, highway, rail system and airport seamlessly to Frankfurt and Germany are closely linked.

\subsection{Both soft and hard facilities are the necessary factors for the economic development of the airport}

Perfect airport operation resources, rich air routes network, convenient passenger transit process, comfortable entertainment facilities are the key elements of building the large-scale international aviation hub indispensable prerequisite. For example, Incheon International Airport has an airport runway that utilizes the world's most advanced technology in airfield facilities. It can safely take off and land when sight visibility is less than 200 meters. In addition, the airport's automatic baggage handling system is extremely advanced, Within the passenger baggage handling transit is completed. Beijing Capital International Airport has a wealth of routes, the world's three major aviation hub as an important transit hub, Air China, China Southern Airlines, China Eastern Airlines, Hainan Airlines and other major domestic airlines are in its establishment of operating base. Changi Airport is complemented by a recreational facility centered on the "guest experience". It also features 5 different themed gardens, a science museum and a 4-storey slide.

\subsection{Complete system of policy support system is necessary to ensure the economic development of the airport}

In a region, it is necessary for the government to play a dominant role in developing the regional economy based on the advantage of airport transportation. For example, Dubai Air City is a typical investment policy to create a shopping 
paradise. First, Dubai to implement a more liberal visa-free policy, the implementation of the 96-hour transit visa-free foreigners, only this one on the increase of nearly 200 million US dollars in revenue; Second, the establishment of many preferential policies in Dubai free trade zone to attract investors, the most successful The free trade of capital, free import and re-export tariffs, exempt from personal income tax, no exchange control and other incentives; reimplementation of the concessions Of the tariff policy, the general tax rate of 5\%, and another 421 items to the GCC countries are exempt from tariffs. South Korea Incheon Airport Airport City in the airport free trade zone to implement 7 free 3 half ( 7 years free, 3 and a half years) rental concessions and tariff reductions, lower import VAT, special import agricultural tax, fishery tax, And other tax policies to attract the strength of the logistics companies and enterprises stationed. Schiphol Airport encourages the development of air transport enterprises, the introduction of relevant tax incentives and economic subsidies, such as tax relief for the airport, reduction of airline take-off and landing fees, the implementation of the pilot personal income tax return, increase route subsidies and other policies.

\section{Enlightenment from the development of airport industry at home and abroad}

First, it has a comprehensive integrated transportation network. The comprehensive integrated transportation network is the basic support for the development of airport industry economic zone and the important factor to be taken into consideration when selecting the site. Only have a good integrated transportation network can ensure the flow of airport passenger and logistics. Developed air transport network is also the key element to ensure the enterprises transport products to the world in the shortest time and at the least cost.

Second, it has a high level of service and service efficiency. The biggest function of the airport is to provide fast and convenient services, so the competition between the airport is actually the efficiency. In addition, the airport's service capacity and service efficiency are also the important key elements of enterprise location.

Third, it has excellent research environment and comfortable living environment. Excellent research environment can provide technical and intellectual support and to attract such as product development, creative and other knowledgeintensive industries. As the senior white-collar workers in the port, they tend to live in workplace which is around the natural environment that requires a higher, comfortable living, the work environment has gradually become an important factor in the enterprise site selection.

Fourth, it developed the trade economy and producer services. The location advantages and strong connectivity of the hub airport give it the natural advantage of developing international trade. In the case of the world hub airport economic behavior of the evolution of the surrounding, the trade economy has become a through-airport economic development of the main line. The strong passenger and cargo distribution capabilities and global accessibility of hub airport also make it a best place for logistics, training, finance, consulting and other productive service industry gathering.

\section{References}

1. CAO Yun-chun. Airport economy - the economic growth space of speed. Beijing: Economic Science Press, 2009.

2. CAO Yun-chun, XI Yan-rong.Analysis of International Experiences of Development of Airport Economy and Reference to China. Market Modernization, 2009, (1).

3. ZHOU Shao-hua, WEI Hui-zhen. The main development mode of airport economy. China's National Conditions and National Strength, 2009, (11).

4. LIU Chun-ling.Analysis of International Experience of Industrial Development in Aviation Economic Zone. World Geography Research, 2014, 23 (4).

5. Liu Daoxing, Ren Xiaoli, etc. Advancing the construction of Zhengzhou Airport Economic Comprehensive Experimental Zone of a number of issues. Regional Economic Review, 2015 (02). 